\title{
TOURISM INTENTION: THE EMPIRICAL INVESTIGATIONS OF PULL, PUSH AND PERCEIVED SECURITY FACTORS IN NIGERIA
}

\author{
Maruf Gbadebo SALIMON* \\ University Utara Malaysia (UUM), School of Business Management, \\ Sintok Kedah, Malaysia, e-mail:salimonmg@gmail.com

\section{Olanrewaju KAREEM} \\ University Malaysia Perlis (UMP), School of Business Innovation and \\ Technopreneurship, Malaysia, Perlis, Malaysia, e-mail:oskareem@gmail.com
}

\author{
Sany Sanuri Mohd MOKHTAR \\ University Utara Malaysia (UUM), School of Business Management, \\ Sintok Kedah, Malaysia, e-mail:sany@uum.edu.my \\ Rushami Zien Bin YUSOFF \\ University Utara Malaysia (UUM), School of Business Management, \\ Sintok Kedah, Malaysia, e-mail:rzy278@uum.edu.my

\section{Abdullahi Hassan GORONDUTSE} \\ University Utara Malaysia (UUM), School of Business Management, \\ Sintok Kedah, Malaysia, e-mail:abdullahi@uum.edu.my
}

\begin{abstract}
Citation: Salimon, M.G., Kareem, O., Mokhtar, S.S.M., Yusoff, R.Z.B., \& Gorondutse, A.H. (2019). TOURISM INTENTION: THE EMPIRICAL INVESTIGATIONS OF PULL, PUSH AND PERCEIVED SECURITY FACTORS IN NIGERIA. GeoJournal of Tourism and Geosites, 25(2), 358-374. https://doi.org/10.30892/gtg.25207-365
\end{abstract}

\begin{abstract}
Tourism industry in recent time has suffered from pervasive insecurity issues which significantly affect the performance of the industry. The aim of this study is to investigate the joint effect of push, pull and perceived security factors on tourism intention in Nigeria. In order to conduct this research, questionnaires were distributed to 650 respondents. Out of the distributed questionnaires, only 310 were eventually used for the analysis. The researchers employed Partial Least Square Structural Equation Modelling (PLS-SEM). The findings of this study reveal that push and pull factors have a positive and significant effect on tourist intention. The result equally shows a negative effect of perceived security factor on tourist intention. The results presented may serve as a direction for academia, policy makers and other practitioners.
\end{abstract}

Key words: Push, pull, perceived security, Nigeria, tourist intention.

\footnotetext{
* Corresponding author
} 


\section{INTRODUCTION}

The benefits of the tourism industry to the economic development of many countries of the world have been globally acknowledged. Recently, the World Travel and Tourism Council (WTTC) (2017), reports that this sector generates US\$7.6 trillion and creates 292 million jobs in 2016 globally. The sector equally accounts for $6.6 \%$ of the total global exports while boosting the total global service exports by 30\%. This awesome performance shows that the sector is a driving force of the economic prosperities by contributing to the growth of GDP of some nations such as Singapore, Spain, South Africa, Gambia, India, Malaysia, and so forth (Esu, 2015; Ohlan, 2017; Yousefi \& Marzuki, 2015). On a global scale, for instance, it is projected that this sector would contribute $4.0 \%$ per annum to USD3,537.1bn (3.5\% of GDP) by 2027 (WTTC, 2017) as shown in Figure 1.

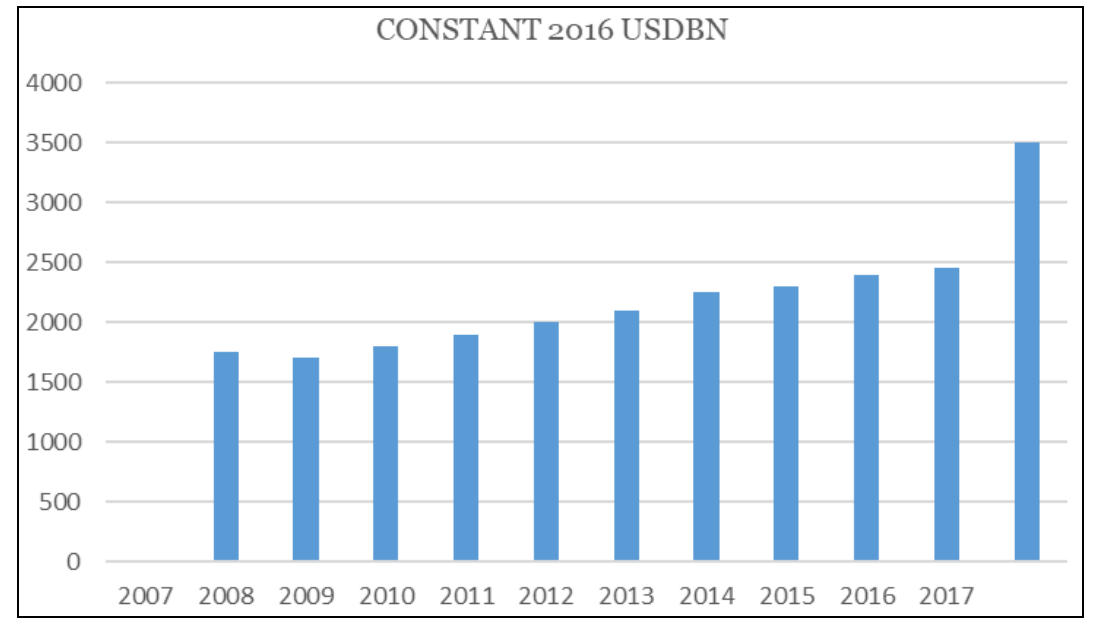

Figure 1. Projected Contribution to Global GDP by Tourism by 2027

(Source: Adapted from WTTC, 2017)

It can, therefore, be argued that the accelerated growth of the tourism industry in many of these countries is due to certain push and pull factors while the governments in the respective nations seem to have deliberately formulated policies that would ensure that the tourists are equally protected and secured when visiting their chosen destinations. Importantly, the push and pull factors concept to tourism motivations which was first theorized by Dann (1977), is now ubiquitous among tourism scholars (e.g. Giddy \& Webb, 2018; Naidoo et al., 2015; Pomfret \& Bramwell, 2014; Su et al., 2018). This approach is regarded useful since it permits the researchers to investigate both the extrinsic and intrinsic factors which propel and draw tourists to pursue particular tourism experiences and destinations (Giddy \& Webb, 2018; Pomfret, 2014). Researches on tourism with respect to the push and the pull factors have included works that identified which factors propel the tourists towards a destination (Aref et al., 2010; Naidoo et al., 2015) while many of these studies have equally established a relationship among these factors (Prayag \& Ryan, 2011; Uysal \& Jurowski, 1994). Additionally, tourism researchers seem to a limited extent, have explored the issue of security that borders on the risk which an individual tourist may face in their voyage to a new destination (e.g., Atuger, 2015; Centizos \& Edge, 2013; Li et al., 2018; Mohseni et al., 2018). These perceived security factors have almost been unanimously agreed to be a debarring issue which seems to inhibit many tourists from performing a voyage to their chosen destinations. 
However, while many of these studies have been conducted and equally provided some useful insights into the impact of push, pull and perceived security factors, the outputs of most of these extant studies are anchored on secondary data analysis of largescale survey research projects which poses major limitation on the range of motivational factors that can be identified empirically (e.g. But \& Ap, 2017). Where some empirical studies on tourism intention based on primary data are however available, most of them have exclusively concentrated on developed countries of Europe and North America (Kim \& Prideaux, 2005; Rittichainuwat, 2008), as empirical researches pertinent to developing nations generally remain inadequate (Yousefi \& Marzuki, 2015). Recently, Yousefi and Marzuki (2015), argued that even though push-pull factors represent substantial factors that account for why people embark on tourism, there is no globally accepted conceptual or theoretical framework to understanding such motives (Huang, 2010). Dean and Shuartanto (2019) also posited that the conceptual explanation and logical linkages between the push and pull motivational factors have not been explored fully. This is in line with the arguments of Han and Hyun (2018) that literature is superficial in explaining the relationship between motivation factors to travel and behavioural intention. This, therefore, calls for a further study that can improve the understanding of the research and practitioners' community of this phenomenon. This, most importantly, would equally have practical relevance for management of destinations, marketers and product developer (Vujko et al., 2018).

Importantly, Nigeria is a country that is richly blessed with cultural and natural resources. Figure 2 depicts the structure of Nigeria as the government of the Nation keeps making concerted efforts to build a viable tourism industry in the last five decades (Esu, 2015). Despite the continuous attempts of the government to market and attract tourists across the globe, it is pathetic that the country has been unable to achieve any meaningful result, thereby, making the industry to be underdeveloped (Dillimono \& Dickinson, 2014).

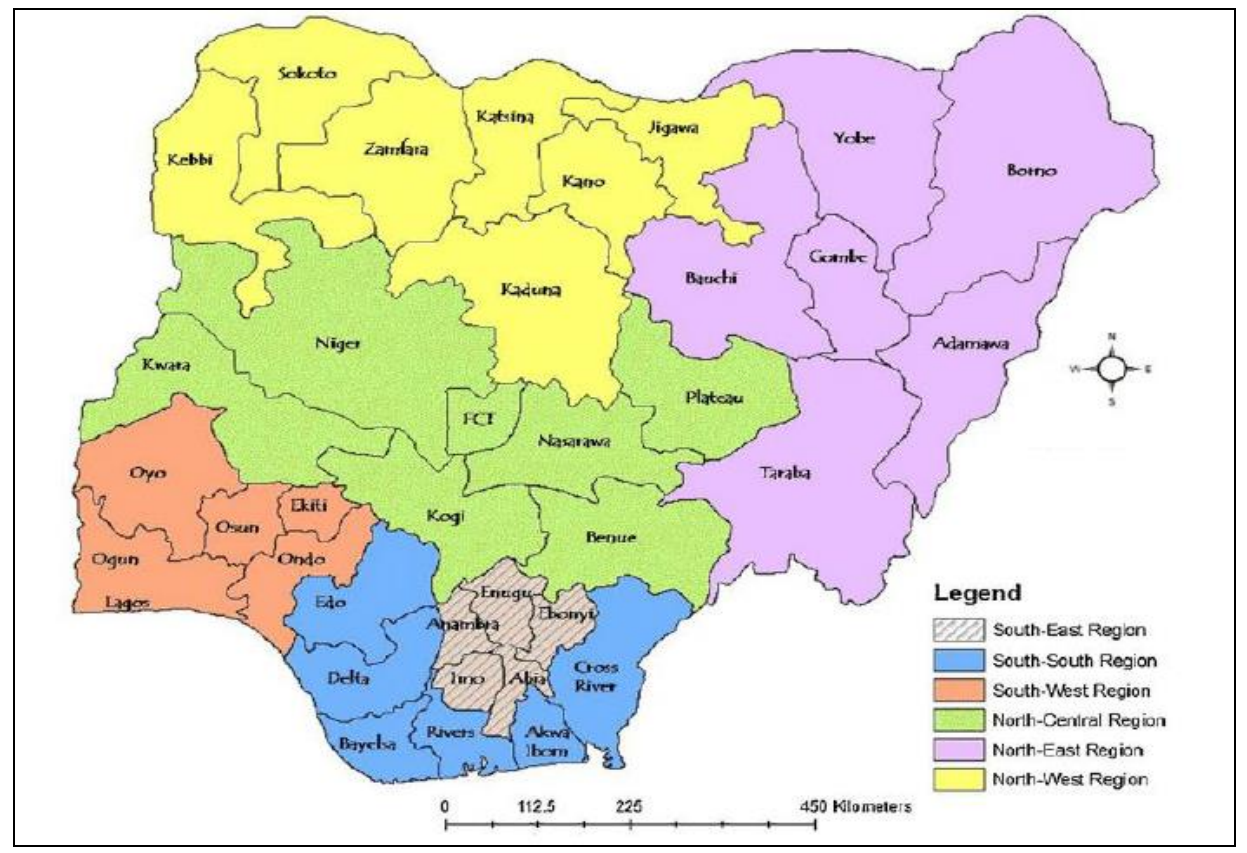

Figure 2. Nigeria Map (Source: Adapted from Federal Government of Nigeria website) 
Evidence has shown that Nigeria has only succeeded in attracting tourists from third world countries such as Benin, Niger, Liberia, Cameroon, Chad and Sudan (Euromonitor International, 2017). This, perhaps explain the reason why the contribution of this sector to GDP of the country is still less than 1\% (Central Bank of Nigeria (CBN) Statistical Bulleting, 2013). The poor performance of this sector is a major concern for the government, the academicians, practitioners and the global community. Given the bad state of the tourism market in Nigeria therefore, the stakeholders have kept asking a recurrent question about how the problem bedevilling the growth of the industry can be solved (Esu, 2015). This study, therefore, proposes that some push and pull factors and security concern are the major factors that could either stimulate or inhibit tourism development in Nigeria. The following structure is used for the other section of this paper. The paragraph that follows the introduction section presented the literature review and theory development. After this, the researchers presented the methodologies, results and discussions of findings while the implications are highlighted.

\section{LITERATURE REVIEW AND THEORY DEVELOPMENT}

The theory of push and pull has been used widely to comprehend the motives of individuals to travel to certain destinations (Zhang et al., 2017). This theory ultimately encompasses both internal and external factors that either serve as propellers or inhibitors to take certain decisions about a choice of a destination. The push factors relate to internal psychological forces which are connected to a particular destination, for instance, taking a leave from routine activities, social interaction, gaining new knowledge about a country and sense of adventure (Kim et al., 2018; Zhang et al., 2017). "Pull" factors such as historic monuments, sunshine, accessibility of location and convenience of facilities are the characteristics of an external environment which entice individuals to particular destinations (Kim et al., 2003). While the majority of previous studies have used this push-pull framework extensively (e.g., Battour et al., 2017; Antón et al., 2017; Yousefi, \& Marzuki, 2015), researchers have largely ignored the issue of security concern that seems to prevent such behaviors (Hsu et al., 2017) especially in developing countries. The security concern has however been cited as the major issue that is preventing tourists from visiting their desired destinations generally (e.g., Ghaderi et al., 2016; Floyd, Gibson, Pennington-Gray \& Thapa, 2004; Silva et al., 2010) and Nigeria in particular (Obieluem et al., 2016).). In view of this, this study considers push and pull factors along the perceived security of the desired destination to predict tourism intention in Nigeria.

\section{PUSH FACTORS AND TOURISM INTENTION}

The 'push' factors emanate from the Abraham Maslow hierarchy of needs theory (Mayo \& Jarvis, 1981). These factors are regarded as those motivational requirements that arise from the state of disequilibrium or tension within the motivational set up of an individual (Kim, et al., 2003; Pryag \& Ryan, 2011). These factors create an intrinsic or intangible urge within an individual traveller to embark on a vacation (Crompton, 1979; Uysal \& Hagan. 1993). In line with the classification of Crompton (1979) cited in Khoung and Ha (2014, p. 490-491), the push factor comprises seven socio-psychological motives which include: "escape, self-exploratory, relaxation, prestige, regression, kinship enhancement, and social interaction" and two cultural motives of "novelty and education". With respect to the push factor, Gray (1970) in his early classification, regards pleasure travellers as wanderlust. This indicates that the travellers in this category emphasise the cultures of destinations, people and landscape (Prayang \& Ryan, 2011). Dann (1977) equally argues that pushing factors can be categorized as 'anomie' and 'ego- 
enhancement'. The former is regarded as the aspiration to escape from the feelings of isolation which accumulate from day-in-day-out or regular daily activities while the latter is a product of the need to achieve recognition and it is attained through the status which travel confers on the travellers (Fodness, 1994). In essence, the push factors are the stimulants within an individual which serve as a driving force to take a decision to travel out of one's present location (Battour et al., 2012). A number of recent researchers have acknowledged that these are the first set of motivations that stimulate an individual to leave their primary abode for another destination (Battour et al., 2012; Khoung \& Ha, 2014; Yousefi \& Marzuki, 2015; Xu \& Chan, 2016). For instance, Yousefi and Marzuki (2015) empirically reported a positive and significant relationship between push factors and travellers intention in Penang, Malaysia. Khoung and Ha (2014) equally found a positive and significant relationship between push factors, the satisfaction of tourists with destination and intention to return among tourists of Vietnam. Battour et al., (2017) explored travel motivation among Muslim Tourists and found that push factors are essential in achieving tourist satisfaction. $\mathrm{Xu}$ and Chan (2016) also found that push motivation significantly contributes to the future behaviour of the tourists. Even though these empirical pieces of evidence seem to show that the push factors are highly essential in motivating tourist to choose their destinations, scholars have advocated for more research in this regard in order to have a comprehensive model that could elicit further understanding of the travel motivation (e.g, Chiang \& Jogaratnam, 2006; Yousefi \& Marzuki, 2015). Hence, we hypothesize as follows:

H1: The push factors have a positive effect on tourism intention in Nigeria.

\section{PULL FACTORS AND TOURISM INTENTION}

Pull factors are described as those factors that determine the choice of where, when, and how the tourist travels (Mill \& Morrison, 1985). These factors relate to the characteristics, attractions, or attributes of the desired destination (Klenosky, 2002) which attract an individual to a specific destination with the objective that those characteristics would satisfy the desires and needs of the tourists (Whyte, 2017). The pull motivation factors represent the possibility of specific attracting factors of a given destination and which align with the travellers' push motivation (Dean \& Shuartanto, 2019; Suni \& Pesonen, 2017). These factors may be intangible or intangible in nature. The intangible represents the travellers' perception, expectation and interpretation of the value and uniqueness of the services received as compared to the home country's services. On the other hand, the tangibles may include the attraction and inexpensiveness of specific facilities, the availability of desired services, staff friendliness and performance during the visit (Dean \& Shuartanto, 2019; Yoon \& Uysal, 2005).

Theory of migration, therefore, posits that the decision to migrate is not only influenced by the characteristics of the original location, but also by the features that are related to the destination (Wong et al., 2016). For instance, if the destination avails a better quality of life with respect to better education and good climate, there is a possibility to migrate to the new destination (Lee, 1966). This, in essence, indicates that there is an interrelationship between pull and push factors and which serves as an underpinning factor for embarking on a journey (Suni \& Pesonen, 2017). Dean and Shuartanto (2019), in this instance, argued that tourists may not use one pull motivation factor, but may employ several factors as far as these factors correspond with the push motivation factors. A number of extant studies have reported a positive and significant relationship between pull factors and tourist intention (Alén et al., 2014; Chang et al., 2014; Dean \& Shuartanto, 2019). David and Shuartanto (2019) reported 
that pull factors influence the tourist intention to repeat the visit. Chang, et al., (2014) found a positive effect of pull factors on the tourism motivations of virtual migrant for social networking sites. Hence, we hypothesize as follows:

H2: The pull factors have a positive effect on tourism intention in Nigeria.

\section{PERCEIVED SECURITY AND TOURISM INTENTION}

The tourism industry in recent time is more susceptible to man-made and natural crises and disasters (Li et al., 2018). Events of these nature have important influences on the tourist sojourn and expenditure (Huan et al., 2004). For instance, WTTC (2017) confirms that when a disaster such as terrorist attack happens, visitor spending automatically declines as the influences of such attacks would be compounded by incorrect or extended travel advisories, making the intending tourists seek for alternative destinations they perceived safer. The safety and security of the intended destination are therefore very paramount in the minds of the travellers (Shin, 2005). Tourists have become sceptical about security situations in Nigeria especially with the incessant terrorist attacks and other man-made crises that are common in Northern part of and some other States of the country (Imhonopi \& Urim, 2016). From the tourists' perspective, the general feeling of being secured while travelling to, and within the choice of their destinations is regarded as an essential factor than any other ones (George, 2003; Hsu et al., 2017). If a tourist perceived that the intended destination is secured, his/her motivation towards the desired destination will be positive while otherwise will make the tourists to perceive the destination to be unsecured. Researchers have paid detail attention to how the tourism industry responds and reacts to different crises and disasters such as financial meltdown (Li et al., 2010; Obradovic et al., 2013), political uncertainty (Elshaer \& Saad, 2017; Ioannides \& Apostolopoulos, 1999), and natural crises (Cró \& Martins, 2017; Wright \& Sharpley, 2016). However, within the context of developing countries such as Nigeria, little attention has been paid to the issue of security concern among tourists despite that the previous studies from other climes of developed nations have reported the significance of secured destinations on tourism intention (e.g. Ghaderi et al., 2016; Hsu et al., 2017; Silva et al., 2010). Hence, we hypothesize as follows:

$\mathrm{H}_{3}$ : Perceived security factors have a negative effect on tourism intention in Nigeria

Considering the background of the study and subsequent literature review, the following conceptual framework is presented:

\section{FRAMEWORK OF THE STUDY}

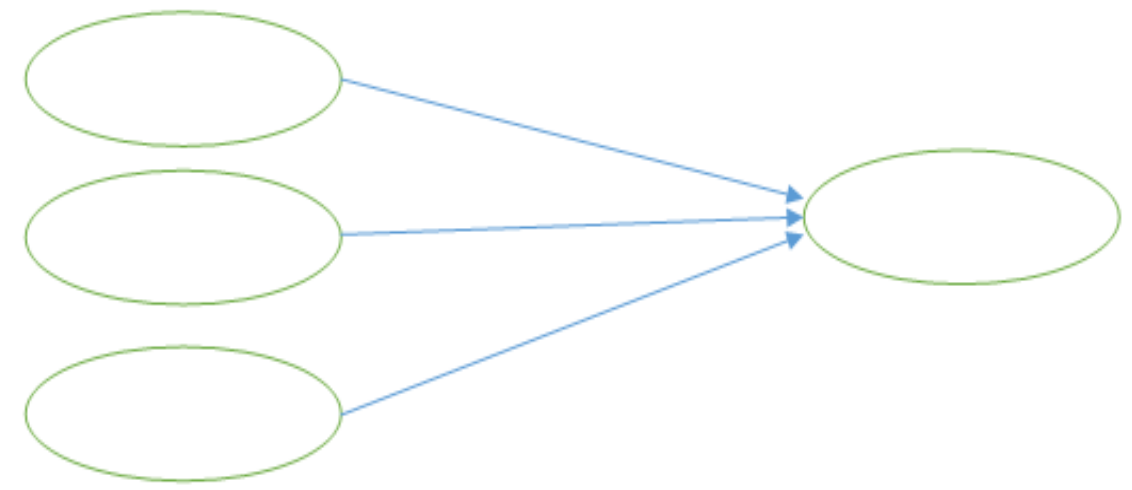

Figure 3. Conceptual Framework 


\section{METHODOLOGY}

\section{STUDY SITE}

Nigeria has a population of about 200 million people and it is one of the largest countries in West Africa (Worldmeter, 2019). The country has two major climatic seasons: a wet season and a dry season. The wet season runs from April to September while the dry season is witnessed between October and March. The dry season is the most favoured season for tourism as this period ushers in many tourists due to favourable climatic condition of the period (Awaritefe, 2003). This study was conducted during the dry season by selecting Benin City, Badagry Beach, and Kainji lake national park. In order to collect the data of this study, a self-administered survey was used.

Table 1. Demographic information

\begin{tabular}{|c|c|c|}
\hline Variables & Descriptions & $\%$ \\
\hline \multirow[t]{2}{*}{ Gender } & Male & 56.3 \\
\hline & Female & 43.7 \\
\hline \multirow[t]{5}{*}{ Age } & $18-25$ & 26.9 \\
\hline & $26-35$ & 44.1 \\
\hline & $36-45$ & 12 \\
\hline & $46-55$ & 7 \\
\hline & 56 and above & 10 \\
\hline \multirow[t]{4}{*}{ Marital Status } & Single & $65 \cdot 3$ \\
\hline & Married & 21.2 \\
\hline & Divorce & 4.1 \\
\hline & Widowed & 9.4 \\
\hline \multirow[t]{5}{*}{ Nationality } & African & 79 \\
\hline & Asian & 4 \\
\hline & European & 9 \\
\hline & American & 6 \\
\hline & Oceanian & 2 \\
\hline \multirow[t]{4}{*}{ Frequency of Visit } & First-Time & 65.4 \\
\hline & Second-Time & 18 \\
\hline & Third-Time & 4 \\
\hline & Three times and above & 12.6 \\
\hline \multirow[t]{6}{*}{ Income } & Less than US $\$ 1500$ & 54 \\
\hline & US $\$ 1501-U S \$ 3500$ & 22 \\
\hline & US\$3501-US\$5500 & 13 \\
\hline & US\$5501-US\$7500 & 4 \\
\hline & US $\$ 7501-U S \$ 10000$ & 3 \\
\hline & Above US\$10000o & 4 \\
\hline \multirow[t]{6}{*}{ Accommodation } & Hotel & 35 \\
\hline & Resort & 21 \\
\hline & Motel & 15 \\
\hline & Home of relatives and Friends & 12 \\
\hline & Apartment & 8 \\
\hline & Others & 9 \\
\hline
\end{tabular}

The researchers divided the questionnaire into four sections. In the first section, demographic information with respect to gender, age, income, level of education, employment, and nationality of the respondents was collected. In the second section, 
Tourism Intention: The Empirical Investigations of Pull, Push and Perceived Security Factors in Nigeria

the researchers collected information on travel features (number of visitation, the period of stay, the objective of visit, travel frequency, and type of accommodation). In the third section, pull, push and perceived security factors were identified. 18 Items related to push, 18 items related to pull and 6 items related to perceived security factors were adapted having comprehensively reviewed literature from previous studies (George 2003; Hsu et al., 2017; Hanqin \& Lam, 1999; Huang \& Hsu, 2008; Sangpikul, 2008; Yousefi \& Marzuki, 2015). All the items were assessed using a 5-point Likert scale with the response which ranges from 5 (Agree Strongly) to 1 (Disagree Strongly).

About 650 questionnaires were distributed by the researchers among foreign tourists at the study sites between October 2017 and March 2018. The researchers were able to retrieve 310 usable responses indicating $47 \%$ of response rates. Table 1 provides demographic information about the respondents while Table 2 classifies the constructs with their items and the sources where the items are adapted as depicted below. Table 1 above shows that the majority of the respondents (56.3\%) are Male tourists while $44.1 \%$ of the tourists are within the age rank of 26-35. The table further shows that the majority of the tourists (54\%) have less than $\$ 1500.00$ (One thousand, five hundred US dollars) income while the largest percentage of 35 of the tourists prefer to stay in the hotel for their period of stay. The information provided by the table equally depicts that $65.3 \%$ of the respondents are having single marital status, $79 \%$ of the respondents are Africans, while $18 \%$ of the respondents, and being the highest, visit the country the second time.

Table 2. Constructs classification, items and their sources

\begin{tabular}{|c|l|c|}
\hline Constructs & \multicolumn{1}{|c|}{ Items } & \multicolumn{1}{|c|}{ Sources } \\
\hline Pull Factor & $\begin{array}{l}\text { I travelled to Nigeria because of the positive } \\
\text { attitude of the residents }\end{array}$ & $\begin{array}{c}\text { Hanqin \& Lam, 1999; Hsu \& } \\
\text { Huang, 2008; Sangpikul, 2008; } \\
\text { Yousefi \& Marzuki, 2015; }\end{array}$ \\
\hline--- & $\begin{array}{l}\text { I travelled to Nigeria because of the positive } \\
\text { attitude of service staff }\end{array}$ & -- \\
\hline--- & $\begin{array}{l}\text { I travelled to Nigeria of the convenience of the } \\
\text { transportation system }\end{array}$ & --- \\
\hline--- & $\begin{array}{l}\text { I travelled to Nigeria because of the quality of } \\
\text { local transportation }\end{array}$ & --- \\
\hline--- & $\begin{array}{l}\text { I travelled to Nigeria because of the quality of } \\
\text { transportation services }\end{array}$ & --- \\
\hline--- & $\begin{array}{l}\text { I travelled to Nigeria because of the convenience } \\
\text { associated with shopping. }\end{array}$ & --- \\
\hline--- & $\begin{array}{l}\text { I travelled to Nigeria because of the ease } \\
\text { associated with shopping. }\end{array}$ \\
\hline--- & $\begin{array}{l}\text { I travelled to Nigeria because of the ease with the } \\
\text { transportation system }\end{array}$ & --- \\
\hline--- & I travelled to Nigeria because the climate is acceptable & -- \\
\hline--- & $\begin{array}{l}\text { I travelled to Nigeria because of the ease of } \\
\text { entry and exit }\end{array}$ & --- \\
\hline--- & $\begin{array}{l}\text { I travelled to Nigeria because the recreation } \\
\text { facilities are attractive }\end{array}$ & ---- \\
\hline--- & I travelled to Nigeria because the beaches are attractive & --- \\
\hline--- & Ibelieved the cultural centres in Nigeria are attractive & --- \\
\hline--- & $\begin{array}{l}\text { I travelled to Nigeria because the cultural centres } \\
\text { have different monuments }\end{array}$ & - \\
\hline--- & I travelled to Nigeria because of different cuisines & - \\
\hline--- & I travelled to Nigeria because it is affordable & - \\
\hline & &
\end{tabular}


Maruf Gbadebo SALIMON, Olanrewaju KAREEM, Sany Sanuri

Mohd MOKHTAR, Rushami Zien Bin YUSOFF, Abdullahi Hassan GORONDUTSE

\begin{tabular}{|c|c|c|}
\hline--- & $\begin{array}{l}\text { I travelled to Nigeria due to the hygiene and } \\
\text { cleanliness of the centres }\end{array}$ & --- \\
\hline--- & $\begin{array}{l}\text { I travelled to Nigeria to see natural landscape } \\
\text { and scenery }\end{array}$ & --- \\
\hline Push Factors & I travelled to see something new & $\begin{array}{l}\text { Hanqin \& Lam, 1999; Hsu \& } \\
\text { Huang, 2008; Sangpikul, 2008; } \\
\text { Yousefi \& Marzuki, 2015; }\end{array}$ \\
\hline--- & I travelled to Nigeria to visit friends and colleagues & --- \\
\hline--- & $\begin{array}{l}\text { I travelled to Nigeria to acquire knowledge of a } \\
\text { new destination }\end{array}$ & --- \\
\hline--- & $\begin{array}{l}\text { I regard travelling as an opportunity to relax in a } \\
\text { new destination }\end{array}$ & --- \\
\hline--- & $\begin{array}{l}\text { I believe that be travelling will enable see } \\
\text { something new }\end{array}$ & --- \\
\hline--- & $\begin{array}{l}\text { I believe travelling will enable me to have } \\
\text { physical relaxation/rest }\end{array}$ & --- \\
\hline--- & $\begin{array}{l}\text { I travelled so that I can share a new experience } \\
\text { with colleagues at home }\end{array}$ & --- \\
\hline--- & Visiting places my friends have visited & --- \\
\hline--- & I travel to escape from physical stress at home & --- \\
\hline--- & $\begin{array}{l}\text { I enjoy every moment with my family during the } \\
\text { vacation }\end{array}$ & --- \\
\hline--- & $\begin{array}{l}\text { I believe travelling to Nigeria enables me to fulfil } \\
\text { my dream of visiting a foreign country }\end{array}$ & --- \\
\hline--- & $\begin{array}{l}\text { I want to visit Nigeria because my friends have } \\
\text { visited the country before }\end{array}$ & --- \\
\hline--- & I travel to escape from my usual daily routines & --- \\
\hline --- & Travelling enables to be happy & --- \\
\hline--- & I travelled to see how other people live their life & --- \\
\hline--- & I travelled to have knowledge of a new destination & --- \\
\hline--- & I travel to enable me to see other groups of people & --- \\
\hline--- & I travelled to see something I don't usually see & --- \\
\hline $\begin{array}{c}\text { Perceived } \\
\text { Security factor }\end{array}$ & I feel secured while touring the city & $\begin{array}{l}\text { George (2003), } \\
\text { Hsu et al., (2017) }\end{array}$ \\
\hline--- & Adequate security is provided during the visit & --- \\
\hline--- & $\begin{array}{l}\text { I will repeat my visit because I feel secured } \\
\text { during this visit }\end{array}$ & --- \\
\hline--- & I feel secure while walking during the day & --- \\
\hline--- & I feel secure while walking during the night & --- \\
\hline--- & I feel secure while using the bus or transportation & --- \\
\hline
\end{tabular}

\section{MODEL ESTIMATION}

In order to test the hypotheses of the study, the researchers used structural equation modelling (SEM). The PLS-SEM approach is used generally by the contemporary researchers because it can accommodate limited sample size, and small latent variables which are not sufficient enough to be accommodated by covariance-based SEM (CB-SEM) (Adeleke et al., 2018; Bamgbade et al., 2018; Salimon et al., 2017). Recent arguments also position that the PLS-SEM is very robust in model estimation while establishing construct validities effectively than CB-SEM (Salimon et al., 2017). The conceptual model includes four reflective unidimensional constructs. In line with Hair et al., (2011), the researchers evaluated the measurement models by conducting three 
Tourism Intention: The Empirical Investigations of Pull, Push and Perceived Security Factors in Nigeria

different tests in order to validate the reflective constructs. The four tests include internal-consistency, indicator-reliability, convergent-validity and discriminant-validity.

Table 3. Measurement Model

\begin{tabular}{|c|c|c|c|c|}
\hline Constructs & Factor Loadings & AVE & $\mathrm{CR}$ & rho_A \\
\hline PF1 & 0.788 & 0.67 & 0.94 & 0.93 \\
\hline PF2 & 0.873 & --- & --- & --- \\
\hline $\mathrm{PF}_{3}$ & 0.788 & --- & --- & --- \\
\hline $\mathrm{PF} 4$ & 0.821 & --- & --- & --- \\
\hline $\mathrm{PF} 5$ & 0.816 & --- & --- & --- \\
\hline PF6 & 0.849 & --- & --- & --- \\
\hline $\mathrm{PF} 7$ & 0.865 & --- & --- & --- \\
\hline PF8 & 0.755 & --- & --- & --- \\
\hline PLF1 & 0.736 & 0.64 & 0.95 & 0.95 \\
\hline PLF2 & 0.775 & --- & --- & --- \\
\hline PLF3 & 0.757 & --- & --- & --- \\
\hline $\mathrm{PLF}_{4}$ & 0.768 & --- & --- & --- \\
\hline $\mathrm{PLF}_{5}$ & 0.773 & -- & --- & --- \\
\hline PLF6 & 0.775 & --- & --- & --- \\
\hline PLF7 & 0.815 & --- & --- & ---- \\
\hline PLF8 & 0.827 & --- & --- & ---- \\
\hline PLF9 & 0.767 & --- & --- & --- \\
\hline PLF10 & 0.769 & --- & --- & --- \\
\hline PLF11 & 0.658 & --- & --- & --- \\
\hline PLF12 & 0.732 & --- & --- & --- \\
\hline PLF13 & 0.705 & --- & --- & --- \\
\hline PLF14 & 0.714 & --- & --- & --- \\
\hline PLF15 & 0.712 & --- & --- & --- \\
\hline PLF16 & 0.69 & --- & --- & --- \\
\hline PLF17 & 0.676 & --- & --- & --- \\
\hline PSF1 & 0.691 & 0.71 & 0.95 & 0.94 \\
\hline PSF2 & 0.836 & --- & --- & --- \\
\hline PSF3 & 0.714 & --- & --- & --- \\
\hline $\mathrm{PSF}_{4}$ & 0.769 & --- & --- & --- \\
\hline $\mathrm{PSF}_{5}$ & 0.847 & --- & --- & --- \\
\hline PSF6 & 0.781 & --- & --- & --- \\
\hline PSF7 & 0.785 & & & \\
\hline PSF8 & 0.79 & --- & --- & --- \\
\hline PSF9 & 0.671 & --- & --- & --- \\
\hline PSF10 & 0.801 & --- & --- & --- \\
\hline PSF11 & 0.807 & --- & --- & --- \\
\hline PSF12 & 0.764 & --- & --- & --- \\
\hline PSF13 & 0.743 & --- & --- & --- \\
\hline TI1 & 0.738 & 0.69 & 0.94 & 0.93 \\
\hline TI2 & 0.829 & --- & --- & --- \\
\hline TI3 & 0.861 & --- & --- & --- \\
\hline TI4 & 0.852 & --- & --- & --- \\
\hline TI5 & 0.825 & --- & --- & --- \\
\hline TI6 & 0.852 & --- & --- & --- \\
\hline $\mathrm{TI} 7$ & 0.863 & --- & --- & --- \\
\hline
\end{tabular}

Note: PF=Push Factors, PLF=Pull Factors, PSF=Perceived Security Factors, TI=Tourist Intention 
Regarding the latent constructs, the loadings of their individual indicators with their composite reliability (CR) are depicted in Table 3 . The values of loadings for the items of each construct range between 0.658 and 0.871 . These values surpass the recommended standard of 0.40 , and which shows that the reliability of individual item is confirmed. Additionally, the values of the CR were equally above the floor standard of o.70, signifying the internal-consistency and reliability of each the latent constructs of the study (Bagozzi et al., 1991). In order to establish convergent validity, the researchers ascertain that the value of average-variance-extracted (AVE) is above the standard of 0.50 indicating that all the values of the AVEs for the respective constructs are within 0.64 to 0.71 , implying that the validity for convergence requirement has been met. Equally, the discriminant validity is established as shown in Table 4. Generally, the results that are generated thereby show that the research's constructs have sufficient degrees of construct validity, internal consistency, convergent validity and discriminant validity.

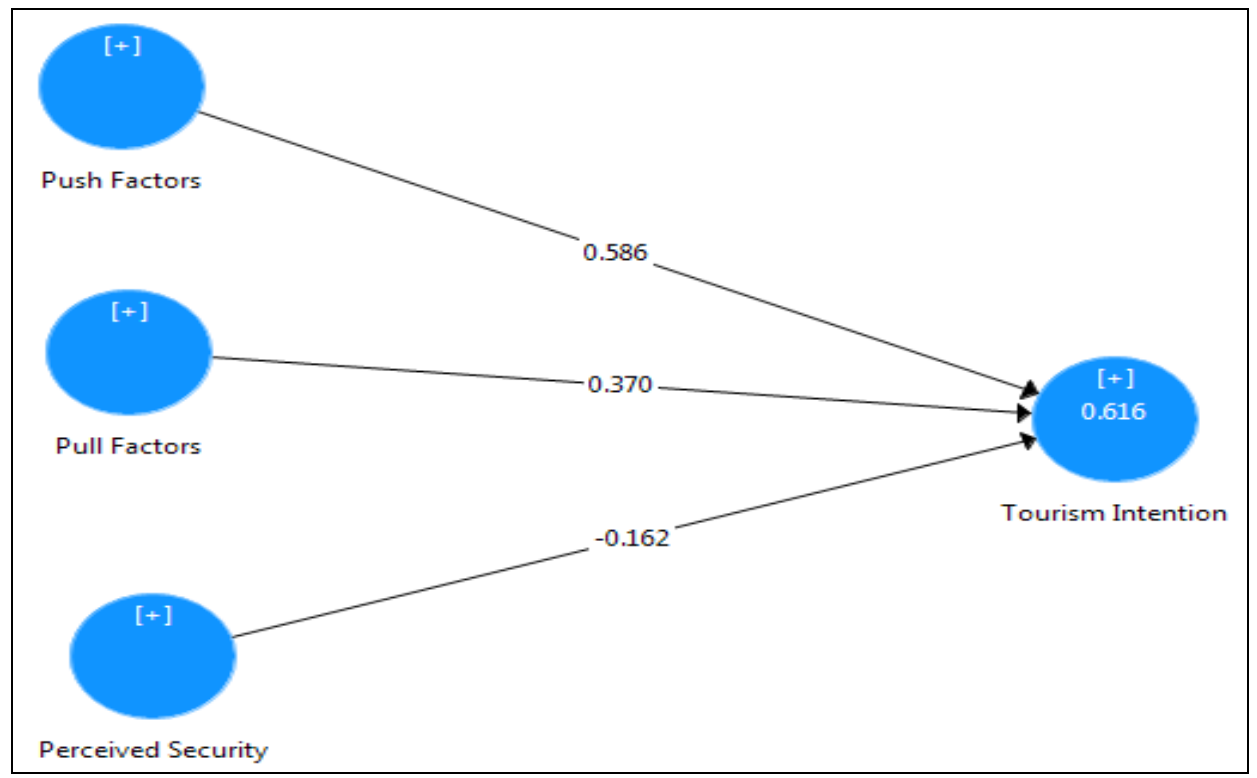

Figure 4. Measurement Model

Table 4. Discriminant Validity (Heterotrait-Monotrait Ratio (HTMT)

\begin{tabular}{|l|l|l|l|l|}
\hline & Perceived Security & Pull Factors & Push Factors & Tourism Intention \\
\hline Perceived Security & --- & --- & --- & --- \\
\hline Pull Factors & $\mathbf{0 . 7 4 6}$ & --- & --- & --- \\
\hline Push Factors & 0.624 & $\mathbf{0 . 7 4 4}$ & --- & --- \\
\hline Tourism Intention & 0.466 & 0.701 & $\mathbf{0 . 8 0 5}$ & --- \\
\hline
\end{tabular}

The next step in the SEM with respect to structural model requires testing of hypothesis. As indicated in Table 5 and based on information extracted from figure 2 and 3 , push factors significantly influenced tourism intention $(b=0.586, p<0.001)$. Pull factors also influenced tourism intention $(\mathrm{b}=0.370, \mathrm{p}<0.001)$. Moreover, perceived security equally influenced tourism intention negatively and significantly $(\mathrm{b}=-0.162, \mathrm{p}<$ o.001). These results indicate that $\mathrm{H} 1, \mathrm{H} 2$, and $\mathrm{H}_{3}$ hypotheses are supported. 


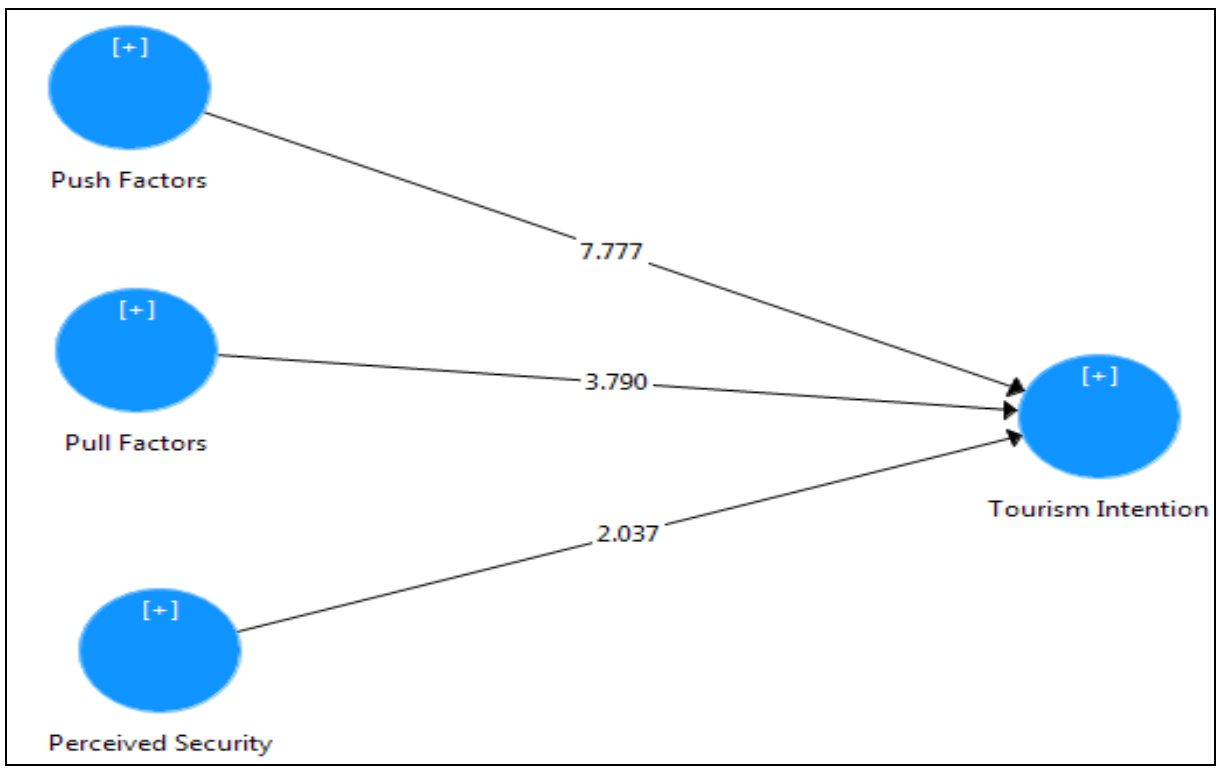

Figure 5. Structural Model

Table 5. Structural Model Result - Notes: ${ }^{* * *} \mathrm{p}<0.001 . \mathrm{R}^{2}=0.616$

\begin{tabular}{|l|c|c|c|c|c|}
\hline \multicolumn{1}{|c|}{ Paths } & b & Standard Error & t-value & P Values & Decision \\
\hline $\begin{array}{l}\text { PF -> Tourism } \\
\text { Intention }\end{array}$ & $0.586^{* * *}$ & 0.075 & 7.777 & 0.000 & Supported \\
\hline $\begin{array}{l}\text { PLF -> Tourism } \\
\text { Intention }\end{array}$ & $0.370^{* * *}$ & 0.098 & 3.79 & 0.000 & Supported \\
\hline $\begin{array}{l}\text { PSF -> Tourism } \\
\text { Intention }\end{array}$ & $-0.162^{* * *}$ & 0.08 & 2.037 & 0.000 & Supported \\
\hline
\end{tabular}

\section{PREDICTIVE RELEVANCE AND EFFECT SIZE}

In Table 6, the variance caused $\left(\mathrm{R}^{2}\right)$ by the exogenous variables on the endogenous latent variable as well as predictive relevance $\left(\mathrm{Q}^{2}\right)$ of the model are reported. The $\mathrm{Q}^{2}$ was assessed based on the Stone-Geisser test $\left(\mathrm{Q}^{2}\right)$ (Geisser, 1974). Accordingly, the $\mathrm{Q}^{2}$ of $0.02,0.15$ and 0.35 indicate small, medium, and large predictive relevance accordingly. By virtue of this, push, pull and perceived security factors are regarded to have adequate predicting power since their values are $0.35,0.17$, and 0.38 respectively. The $\mathrm{R}^{2}$ value of 6.16 per cent as obtained is equally above the minimum standard.

Table 6. Predictive Relevance $\left(\mathrm{Q}^{2}\right)$ and Effect Size $\left(\mathrm{F}^{2}\right), \mathrm{NA}=$ Not Applicable

\begin{tabular}{|l|c|c|c|}
\hline & $\mathbf{R}^{\mathbf{2}}$ & $\mathbf{Q}^{\mathbf{2}}$ & $\mathbf{f}^{\mathbf{2}}$ \\
\hline Tourist Intention & 6.16 & N/A & N/A \\
\hline Push Factors & N/A & 0.16 & 0.092 \\
\hline Pull Factors & N/A & 0.36 & 0.506 \\
\hline Perceived Security & N/A & 0.38 & 0.572 \\
\hline
\end{tabular}

Thus, the research frame work of this study possesses the desired predictive power in explaining the tourism intention. Additionally, the effect-size $\left(\mathrm{F}^{2}\right)$, which shows the empirical-power of the study framework is equally ascertained. Based on the 
suggestion of Cohen (1988), $\mathrm{f}^{2}$ values of $0.02,0.15,0.35$ indicate small, medium, and large effect size respectively for a particular endogenous construct. In this regard, the $\mathrm{f}^{2}$ of this research is acceptable based on medium and large effect sizes.

\section{DISCUSSION OF FINDINGS}

The primary purpose of this research is to test the influence of push, pull and perceived security factors on tourist intention in Nigeria. In this regard, the empirical results of this research support the proposed hypotheses. The statistical results revealed that Push and pull factors positively influence tourist intention. Previous studies have reported similar findings (Prayag \& Ryan, 2011; Yousefi \& Marzuki, 2015) indicating that when travellers have stronger intrinsic desires to go on a vacation and positive perception towards the features, attractions, or attributes of a specific destination, they may get intention to visit their choice of destinations.

This in line with the arguments of previous studies that seem to agree that travel motivation such as psychological motives and destination attributes positively influence the intention of tourist to visit. Importantly, the results indicate that the push factors are connected with the tourist's internal motivation, however, the pull factors in the form of destination features and characteristics are very exigent to further cause a tourist to begin a journey. This, therefore, shows that there is an interrelationship between the two factors for the tourist intention to be sustained. In this regard, the question whether push factors such as the motivation to escape from the usual routines, the need to have new experiences, the desire to meet new people and see a new culture or to enjoy new cuisines can only come to reality if the pull facilities are actually available. An average tourist wants to relate his experience back home or feel different after a visit to a new destination, achieving this requires a destination that makes these desires to come to fore and this is what the findings of this research are revealing with respect to the push and pull factors.

The relationship between perceived security and tourist intention was negative and equally supported in line with the stated hypothesis. This confirms the findings of previous studies (e.g., Artuğer, 2015; Çetinsöz \& Ege, 2013; Gut \& Jarrell, 2007) thereby indicating that perception of security and safety of chosen destination is a major concern when tourists decide to visit a place. A place perceived to be secure seems to attract tourists while destination perceived to be unsafe and insecure seems to repel travellers and this is what our negative finding is pointing at.

If tourists feel unsecured or threatened about a particular destination, they can form a negative perception of that destination. The negative perceptions come from the risks that are involved when a journey is performed and which may render invalid the good attributes (pull) of the destination. Aside, even though the tourists may have the urge to visit a place, negative related experience concerning lack of security from the previous tourists may debar other intending tourists from executing their intention. Fekete (2012) has initially argued that tourist consultants often refuse to recommend destinations they feel that are not secured to their clients even though the clients are so much interested in those destinations.

\section{IMPLICATIONS OF FINDINGS}

The results of this research contribute significantly to debates on tourism in developing countries generally, and Nigeria in particular. Recent studies on tourism in developing countries seem to point to the fact that much still needs to be done as our findings are of different manifolds. First, this research identified the most significant 
push/pull factors which stimulate and attract tourists to choose their desired destinations. The factors used in this study and their associated measuring items can be adopted by future researchers of destination marketing especially in Nigeria and developing countries generally thereby increasing further understanding of the factors that may underpin the improved performance of tourism industry.

Similarly, the findings of this study with respect to perceived security clearly show that when tourists perceived their intending destinations not to be secured, they tend to develop negative perception. This negative perception seems to have a serious drawback for the industry thereby calling for proper understanding of such factors. Although perceived security risks may be viewed from different perspectives, their consequences are often shocking while negatively impacting the tourism industry (Law, 2006). It may, therefore, be beneficial for the tourist professionals to have a better understanding of these influences in order to plan and implement marketing activities (Cetinso"z \& Ege, 2013). When these factors are well defined and understood, marketers and suppliers can readily give assurances to the likely tourists that their concerns have been considered and well addressed. When this is done, the industry will substantially minimize the risks that are related to the visitation barriers by reducing the level of perceived risk factors. Our findings are also exigent for the policymakers in Nigeria. The issue of insecurity seems to be endemic in Nigeria as the country has witnessed a lot of terrorist attacks in the recent past.

These incidents seem to have a major negative influence on the tourism industry. And, as researches have indicated, every tourist has a good reason (s) to fear crime, since they are more exposed to the crime or other forms of violence than the residents. In order to reduce the tourists' fear therefore, the tourism industry and as well the security enforcement agencies should cooperate to execute crime prevention mechanisms. For example, while the visitors arrive, they should be given tourist information guide which advises them of the differences in the mode of transportation, the different times and routes of the cabs, and so on.

It is equally important that the security measures be improved in order to make the places to be visited protected and to give assurances to the tourists that they can go out in the night while the public transportation is equally made safer. Consequentially, these safety measures would help the visitors to spread their spending across a wider range of amenities, such as theatres, restaurants, and leisure facilities instead of hotels and tourist resorts as indicated in the demographic information.

Based on the findings of this research, it is very important that the government comes up with policies and pronouncements that would give assurances to would be visitors that Nigeria as an intending destination for tourism is secured. The implication is equally important for the marketers of the tourism industry in Nigeria.

Since this industry is growing faster across the globe, the marketing practitioners need to keep providing and updating information about the safety, the nature of facilities and other important available amenities that could propel the intending travellers to consider Nigeria as a destination to be visited. A form of collaboration with the government and other stakeholders in this regard could go a long way to achieve the objective of improving the rate of patronage of this sector.

From the academic perspective, this study has been able to contribute to the discussion on tourism and the findings of this study could be a starting point for academic researchers who may be interested in the issue of tourism in a developing country like Nigeria. Due to the parsimony nature of the model of the study, researchers can draw solution or draw a guide when conducting their research. 


\section{LIMITATION AND FUTURE RESEARCH RECOMMENDATION}

This study has a number of limitations that may be considered while its results are being interpreted. First, the sample used in this study may not represent the entire population of tourists to Nigeria since we collect our data conveniently.

This method of data collection was used as there is no specific and sample frame for tourists. The second limitation centres on the scope of investigation as the study only focused on three popular tourist centres in Nigeria: Benin City, Badagary beach, and Kainji lake national Park which might equally limit the generalizability of the research findings. In addition to this, the study only considered pull, push and perceived security factors within a one-time frame to predict tourist intention while the model of the study only predicted 6.61 per cent of the total variance of the dependent variable. In this realm, future studies may consider longitudinal perspectives and equally perform a comparison study among various destinations in Nigeria and among other West African countries.

Conducting such studies may improve the predictive power of our model. Third, this research only considered international tourists at the expense of local or domestic tourists. It is, therefore, exigent for future study to examine these factors from both perspectives in order to collect more useful information that may guide decision makers.

\section{REFERENCES}

Adeleke, A.Q., Bahaudin, A.Y., Kamaruddeen, A.M., Bamgbade, J.A., Salimon, M.G., Khan, M.W.A., \& Sorooshian, S. (2018). The influence of organizational external factors on construction risk management among Nigerian constructioncompanies. Safety and Health at Work, 9(1), 115-124.

Alén, E., Nicolau, J. L., Losada, N., \& Domínguez, T. (2014). Determinant factors of senior tourists' length of stay. Annals of Tourism Research, 49, 19-32.

Antón, C., Camarero, C., \& Laguna-García, M. (2017). Towards a new approach ofdestination loyalty drivers: Satisfaction, visit intensity and tourist motivations. Current Issues in Tourism, 20(3), 238-26o.

Aref, B., Mohammad, M. A., Puad, A., \& Som, M. (2010). An analysis of push and pull travel motivations of foreign tourists to Jordan. International Journal of Business and Management, 5(12), 41-50.

Artuğer, S. (2015). The effect of risk perceptions on tourists' revisit intentions. European Journal of Business and Management, $7(2), 36-43$.

Awaritefe, O. D. (2003). Destination environment quality and tourists' spatial behaviour $\quad$ in Nigeria: a case study of third world tropical Africa. International Journal of Tourism Research, 5(4), 251-268.

Bagozzi, R.P., Yi, Y., \& Phillips, L.W. (1991). Assessing construct validity in organizational research. Administrative science quarterly, 421-458.

Bamgbade, J. A., Kamaruddeen, A. M., Nawi, M. N. M., Yusoff, R. Z., \& Bin, R. A. (2018). Does government support matter? Influence of organizational culture on sustainable construction among Malaysian contractors. International Journal of Construction Management, 18(2), 93-107.

Battour, M., Ismail, M. N., Battor, M., \& Awais, M. (2017). Islamic tourism: an empirical examination of travel motivation and satisfaction in Malaysia. Current Issues in Tourism, 2O(1), 50-67.

But, J. W. P., \& Ap, J. (2017). The impacts of casino tourism development on Macao residents' livelihood. Worldwide Hospitality and Tourism Themes, 9(3), 260-273.

Çetinsöz, B.C., \& Ege, Z. (2013). Impacts of perceived risks on tourists' revisit intentions. Anatolia, 24(2), $173-187$.

Chang, I. C., Liu, C. C., \& Chen, K. (2014). The push, pull and mooring effects in virtual migration for social networking sites. Information Systems Journal, 24(4), 323-346.

Cohen, J. (1988). Statistical power analysis for the behavioural sciences.

Cró, S., \& Martins, A. M. (2017). Structural breaks in international tourism demand: Are they caused by crises or disasters?. Tourism Management, 63, 3-9.

Crompton, J. L. (1979). Motivations for pleasure vacation. Annals of tourism research, 6(4), 408-424.

Dean, D., \& Suhartanto, D. (2019). The formation of visitor behavioral intention to creative tourism: the role of push-Pull motivation. Asia Paific Journal of Tourism Research, vol 24, Issue 5, 393-404. 
Dillimono, H. D., \& Dickinson, J. E. (2014). Travel, tourism, climate change, and behavioral change: travelers' perspectives from a developing country, Nigeria.Journal of Sustainable Tourism, 23(3), 437-454.

Elshaer, I. A., \& Saad, S. K. (2017). Political instability and tourism in Egypt: Exploring survivors' attitudes after downsizing. Journal of Policy Research in Tourism, Leisure and Events, 9(1), 3-22.

ESU, B.B. (2015). Transforming the Nigeria tourism industry through tourism entrepreneurial development. African Journal of Business Management, 9(15), 569-580.

Federal government of Nigeria retrieved from http://www.nig.gov.org history of Nigeria/21/04/2019.

Fekete, A. (2012). Safety and security target levels: Opportunities and challenges for risk management and risk communication. International Journal of Disaster Risk Reduction, 2, 67-76.

Floyd, M. F., Gibson, H., Pennington-Gray, L., \& Thapa, B. (2004). The effect of risk perceptions on intentions to travel in the aftermath of September 11, 2001. Journal of Travel \& Tourism Marketing, 15(2-3), 19-38.

Giddy, J. K., \& Webb, N. L. (2018). The influence of the environment on adventure tourism: from motivations to experiences. Current issues in tourism, 21(18), 2124-2138.

Geisser, S. (1974). A predictive approach to the random effect model. Biometrika, 61(1), 101-107.

George, R. (2003). Tourist's perceptions of safety and security while visiting Cape Town. Tourism Management, 24(5), 575-585.

Gut, P., \& Jarrell, S. (2007). Silver lining on a dark cloud: The impact of 9/11 on a regional tourist destination. Journal of Travel Research, 46(2), 147-153.

Hair, J. F., Ringle, C. M., \& Sarstedt, M. (2011). PLS-SEM: Indeed a silver bullet. Journal of Marketing theory and Practice, 19(2), 139-152.

Hanqin, Z. Q., \& Lam, T. (1999). An analysis of Mainland Chinese visitors' motivations to visit Hong Kong. Tourism Management, 20(5), 587-594.

Hsu, S. C., Lin, C. T., \& Lee, C. (2017). Measuring the effect of outbound Chinese tourists travel decision making through tourism destination image and travel safety and security. Journal of Information and Optimization Sciences, $38(3-4), 559-584$.

Huan, T. C., Beaman, J., \& Shelby, L. (2004). No-escape natural disaster: Mitigating impacts on tourism. Annals of Tourism Research, 31(2), 255-273.

Huang, S. (2010). Measuring tourist motivation: Do scales matter? Tourismos: An International Multidisciplinary Journal of Tourism, 5(1), 153-162.

Huang, S., \& Hsu, C. H. (2008). Recent tourism and hospitality research in China. International Journal of Hospitality \& Tourism Administration, 9(3), 267-287.

Imhonopi, D., \& Urim, U. M. (2016). The Spectre of Terrorism and Nigeria's industrial development: A multistakeholder imperative. African Journal of Criminology and Justice Studies: AJCJS, 9(1), 20-40.

Ioannides, D., \& Apostolopoulos, Y. (1999). Political instability, war, and tourism in Cyprus: Effects, management, and prospects for recovery. Journal of Travel Research, 38(1), 51-56.

Kim, M. J., Lee, C. K., Petrick, J. F., \& Hahn, S. S., (2018), Factors affecting international event visitors' behavioral intentions: the moderating role of attachment avoidance. Journal of Travel \& Tourism Marketing, 1-16.

Kim, S. S., \& Prideaux, B., (2005), Marketing implications arising from a comparative study of international pleasure tourist motivations and other travel-related characteristics of visitors to Korea. Tourism Management, 26(3), 347-357.

Kim, S. S., Lee, C. K., \& Klenosky, D. B. (2003). The influence of push and pull factors at Korean national parks. Tourism management, 24(2), 169-180.

Klenosky, D.B. (2002). The "pull" of tourism destinations: A means-end investigation. Journal of travel research, 40(4), 396-403.

Law, R. (2006). Internet and Tourism-Part XXI: TripAdvisor.Journal of Travel \& Tourism Marketing, 20(1), 75-77.

Lee, E. S. (1966). A theory of migration. Demography, 3(1), 47-57.

Li, F., Wen, J., \& Ying, T. (2018). The influence of crisis on tourists' perceived destination image and revisit intention: An exploratory study of Chinese tourists to North Korea. Journal of Destination Marketing \& Management, 9, 104-111.

Li, S., Blake, A., \& Cooper, C. (2010). China's tourism in a global financial crisis: a computable general equilibrium approach. Current Issues in Tourism, 13(5), 435-453.

Mayo, E. J., \& Jarvis, L. P. (1981). The psychology of leisure travel. Effective marketing and selling of travel services. CBI Publishing Company, Inc.

Mill, R. C., \& Morrison, A. M. (1985). The tourism system. Englewood Cliffs. Prentice-Hall. national parks. Tourism Management, 24(2), 169-180. 
Mohseni, S., Jayashree, S., Rezaei, S., Kasim, A., \& Okumus, F. (2018). Attracting tourists to travel companies' websites: the structural relationship between website brand, personal value, shopping experience, perceived risk and purchase intention. Current Issues in Tourism, 21(6), 616-645.

Naidoo, P., Ramseook - Munhurrun, P., Seebaluck, N.V., \& Janvier, S. (2015). Investigating the motivation of baby boomers for adventure tourism. Procedia - Social and Behavioral Sciences, 175, 244-251.

Obieluem, U. H., Anozie, O. O., \& Nwankwo, E. A. (2016). A study on safety and security issues at selected tourist sites in Easter Nigeria. International Journal of Research in Arts and Social Sciences, 9(1), 66-77.

Obradovic, S., Lekovic, M., \& Pantic, N. (2013). Consequences of global financial crisis for tourism industry in Montenegro and Serbia: a comparative analysis. Actual Problems of the Economy, (6), 373-380.

Pomfret, G., \& Bramwell, B. (2014). The characteristics and motivational decisions of outdoor adventure tourists: A review and analysis. Current Issues in Tourism, 1-32.

Prayag, G., \& Ryan, C. (2011). The relationship between the 'push'and 'pull'factors of a tourist destination: The role of nationality-an analytical qualitative research approach. Current Issues in Tourism, 14(2), 121-143.

Rittichainuwat, B. N., Qu, H., \& Mongkhonvanit, C. (2008). Understanding the motivation of travelers on repeat visits to Thailand. Journal of Vacation Marketing, 14(1), 5-21.

Salimon, M. G., Yusoff, R. Z. B., \& Mohd Mokhtar, S. S. (2017). The mediating role of hedonic motivation on the relationship between adoption of e-banking and its determinants. International Journal of Bank Marketing, 35(4), 558-582.

Sangpikul, A. (2008). Travel motivations of Japanese senior travellers to Thailand. International Journal of Tourism Research, $10(1), 81-94$.

Shin, Y. S. (2005). Safety, security and peace tourism: The case of the DMZ area. Asia Pacific Journal of Tourism Research, $10(4), 411-426$.

Silva, O., Reis, H., \& Correia, A. (2010). The moderator effect of risk on travel decision making. International Journal of Tourism Policy, 3(4), 332-347.

$\mathrm{Su}$, D. N., Johnson, L. W., \& O’Mahony, B. (2018). Analysis of push and pull factors in food travel motivation. Current Issues in Tourism, 1-15.

Suni, J., \& Pesonen, J. (2017). Hunters as tourists - an exploratory study of push-pull motivations. Scandinavian Journal of Hospitality and Tourism, 1-17.

Uysal, M., \& Hagan, L.A.R. (1993). Motivation of pleasure travel and tourism. Encyclopedia of hospitality and tourism, 21, 798-810.

Uysal, M., \& Jurowski, C. (1994). Testing the push and pull factors. Annals of Tourism Research, 21,844-846.

Whyte, L. J. (2017). Understanding the relationship between push and pull motivational factors in cruise tourism: A canonical correlation analysis. International Journal of Tourism Research, 19(5), 557-568.

Wong, J.Y., Lee, S.J., Lee, \& W.H. (2016). Does it Really Affect Me? Tourism Destination Narratives, Destination Image, and the Intention to Visit: Examining the Moderating Effect of Narrative Transportation. International Journal of Tourism Research, 18(5), 458-468.

Wright, D., \& Sharpley, R. (2018). Local community perceptions of disaster tourism: the case of L'Aquila, Italy. Current Issues in Tourism, 21(14), 1569-1585.

Vujko, A., Tretiakova, T.N., Dimitrić, D., Petrović, D.M., Radovanović, M., \& Vuković, D. (2018). Demographic Monitoring snd Forecasting Tourists'arrivals as a means of overcoming seasonality. GeoJournal of Tourism and Geosites. 22 (2), 524-534.

Xu, J. B., \& Chan, S. (2016). A new nature-based tourism motivation model: Testing the moderating effects of the push motivation. Tourism management perspectives, 18, 107-110.

Yoon, Y., \& Uysal, M. (2005). An examination of the effects of motivation and satisfaction on destination loyalty: A structural model. Tourism Management, 26, 45-56.

Yousefi, M., \& Marzuki, A. (2015). An analysis of push and pull motivational factors of international tourists to Penang, Malaysia. International Journal of Hospitality \& Tourism Administration, 16(1), 40-56.

Zhang, W., Williams, S. J., Wang, X., \& Chen, J. (2017). Push and pull factors determine adolescents' intentions of participation in nature observation: Reconnecting local students with nature in China. Applied Environmental Education \& Communication, 16(4), 247-261.

*** Central Bank of Nigeria (2013). Statistical Bulletin. Retrieved from http://www.cenbank.org/Out/2014/ SD/2013Q3\%20Statistical\%2oBulletin\%20Reports_Final.pdf.

*** Euromonitor International (2017). Industries, travel and tourism. http://www.euromonitor.com/.

*** WTTC. (2017). Travel \& Tourism: Global Economic Impact \& Issues 2017.

*** Worldmeter (2019). World Population Report retrieved from http://www.worldometers.info/worldpopulation/nigeria-population.

Submitted:

11.12.2018
Revised:

15.04.2019
Accepted and published online 07.05.2019 